\title{
Agrochemical Characterization of Soils from Cluj County
}

\author{
Stefan BAKOS ${ }^{1}$, Marilena MARGHITAS ${ }^{2 *}$ \\ ${ }^{1}$ Soil and Agrochemical Studies Office Cluj, Fagului Street no. 1, Cluj-Napoca, Romania; \\ ${ }^{2}$ University of Agricultural Sciences and Veterinary Medicine Cluj-Napoca, 3-5, Mănăștur Street, \\ 400372, Cluj-Napoca, Romania; \\ * corresponding author: mmarghitas@usamvcluj.ro
}

Bulletin USAMV series Agriculture 71(2)/2014

Print ISSN 1843-5246; Electronic ISSN 1843-5386

DOI 10.15835/buasvmcn-agr: 10284

\begin{abstract}
This paper refers to an area of 667,400 ha, of which 426,177 ha of agricultural land. This area is situated in the north western Romania, comprising 86 administrative territories from Cluj County. The authors present a brief description of pedologyc-climatic conditions with reference to the relief, geology, climate, hydrological description, factors which lead to the formation of the soil blanket. In its activity, Soil and Agrochemical Studies Office Cluj has conducted numerous pedologycal and agrochemical studies, including soil analysis. These studies have highlighted among other, the agrochemical parameters of soils in the mentioned area. Soil reaction: moderately to strong acidic more than 84,000 ha, 20,000 ha moderately alkaline and strongly alkaline over 500 ha, reserve of humus $(0-50 \mathrm{~cm})$ very small and small 147,000 ha, 118 ha moderate, high and very high 160,000 ha, low and very low in nitrogen content 319,000 ha, 54,000 ha medium, large and very large 52,000 ha, low and very low content of phosphorus over 323,000 ha, 82,000 ha medium, high and very high over 20,000 ha, low and very low content of potassium 18,000 ha, 134,000 ha medium, high and very high over 270,000 ha. Summarizing the above, we conclude that prevention of soil degradation from an agrochemical point of view, as well as improvement of fertility can be done only through profound knowledge and inventory of agrochemical characteristics of the soils.
\end{abstract}

Keywords: agro-chemistry, resources, limitative, productive.

\section{INTRODUCTION}

Taking into account a wide variety of pedologyc-climatic conditions, soils differ greatly through morphological, physical and chemical characteristics, as well as in terms of fertility and productive potential (Bakoș, 1994; Bakoș and Miclăuș, 2001).

The often use of wrong or inadequate technologies for cultures don't only affects quantities and quality of agricultural production, but also put in danger the reserve of soil, which, as we know is limited and cultivated surfaces decreases year to year due to the massive removal of lands from the agricultural circuit (Bakoș, 2001; Rusu et al., 2005; Mărghitaș et al., 2011).

Agriculture in Cluj area aligned with the trends of the last decades, that of applying modern production technologies along with the massive use of chemical substances to increase agricultural production, afterwards inevitably followed by reports of adverse effects on the environment and soils.

Even if it is not considered an area of high agricultural potential, in Cluj County major interventions took place on the fields, with important implications for present and future evolution of soils.

As a result it fully justifies the modern pedology and agrochemical researches, followed by a technical base and also a plan to use the most appropriate scientific measures in order to increase crop production in terms of soil conservation correlated with the most of the environment's demands. 


\section{MATERIALS AND METHODS}

The research was conducted within the territory from Cluj County on an area of 426,177 ha, representing the area of agricultural lands from the total of 667,400 ha. Surface structure on the main categories of usage is presented in Table 1.

Description of specific pedologyc-climatic conditions of the studied area, the delineation and definition of soil units and lands as well as analysis of the main chemical characteristics of the soil was done using Soil Assessment Study Methodology (Vol. I, II, III), developed by ICPA Bucharest 1987 (Florea et al., 1987) as well as Romanian System of Soil Taxonomy - SRTS (Florea and Munteanu, 2012).

Determination of soil analysis was done using the following methods: Ph - using Electrometry, humus - Walklez-Black, total nitrogen - Kieldahl, mobile phosphorus- flamfotometric, mobile potassium - color-metrically.

\section{RESULTS AND DISCUSSIONS}

Cluj County is located in the central-west of the country, between the parallel $27^{0} 28^{\prime}$ North and $46^{\circ} 24^{\prime}$ South and between the meridians of $23^{\circ} 33^{\prime}$ West and $24^{0} 13^{\prime}$ East. The total area of the county is 6,674 square kilometers, including three major relief units: the Transylvanian Plain, the Apuseni Mountains and Somesan Plateau.

Therefore the relief is predominantly hilly, mountainous area occupying about 30\% of the county area. The minimum altitude is located at the exit of river Somes from the county (227 m) and the maximum is situated on top of Vladeasa (1842 m).

The mountain area situated in the southwestern part of the county and is represented by the mountains: Mount Vladeasa, The Big Mountain, Gilau mountains in the south-west and Trascau mountains in the south-east.

The hilly area contains the southeast Somesan Plateau and north-western Transylvanian Plain as well as the massive of Feleac.
Actual lowlands (below $200 \mathrm{~m}$ altitude) are completely absent, their place being filled by the meadows of Somes, Small Somes, Aries and Nadas. Geologically, the situation is in a similar way highly variable: petrographyc diversity of mountain areas (granite intrusions, igneous, crystalline schist, Mesozoic and Paleozoic limestones) and also hilly areas (deposits of marls, marl-clay, sandstone, tuff from Dej) contributed to the formation of large subsoil resources.

In terms of hydrography the most important resource is represented by the Small Somes, which has formed almost all its hydrographyc basin within the territory of the county. Aries river as a tributary of Mures, has developed a large meadow in the southeast part of the county, making there one of the best agricultural areas. Crisul Repede springs in the western part of the county, with a low economic significance.

Natural lakes are few, but all the more interesting in terms of their genesis (Pike Lake, Tau of Law). Much larger, with economic importance in the fields of hydro-energetic are artificial accumulation lakes: Belis-Fantanele, Tarnita. Also within the artificial lakes enter so called anthropomorphic saline lakes formed by flooding of abandoned mines, which are located in the vicinity of villages like Cojocna, Dej and Turda.

Climate of Cluj County is closely related to geographical position and relief items: while in the mountainous sector average annual temperature does not exceed $2-3^{\circ} \mathrm{C}$, values of multiannual thermal climbs to $8.5^{\circ} \mathrm{C}$ in the south-east of the county. Hilly area shows thermal values that range from 6 to $7^{\circ} \mathrm{C}$. Absolute maximum was recorded in the summer of 1931 in Plain Turda $\left(39^{\circ} \mathrm{C}\right)$ and the absolute minimum dropped to $-35.2^{\circ} \mathrm{C}$ in 1963 in Dej. Rainfall is distributed unevenly on both landforms and throughout the year: over 1.000 $\mathrm{mm}$ in the mountainous area, in the Somesan Plateau 600-650 $\mathrm{mm}$, respectively 550-600 $\mathrm{mm}$ in Transylvanian Plain, in the south-eastern part of the county. Number of days with frost is 160 days

Tab. 1. Structure of agricultural areas by the main categories of use (ha)

\begin{tabular}{cccccc}
\hline Arable & Pastures & Meadows & Vineyards & Orchards & Total Agricultural \\
\hline 182,140 & 153,617 & 85,635 & 247 & 4,538 & 426,177 \\
$42.74 \%$ & $36.04 \%$ & $20.10 \%$ & $0.06 \%$ & $1.06 \%$ & $100 \%$ \\
\hline
\end{tabular}


Tab. 2. The main soil types and associations from Cluj County

\begin{tabular}{clcc}
\hline No. & WRB-SR-1998 & Agricultural (ha) & $\%$ \\
\hline 1 & Dystric leptosols (dy,eu, eu-li) & 825 & 1.2 \\
\hline 2 & Regosols (dy,eu,mo) & 76,711 & 18 \\
\hline 3 & Alenosols ((pr,dy,eu,ca) & 8,523 & 10 \\
\hline 4 & Fluvisols (dy,eu,ca.gl) & 42,617 & 3 \\
\hline 5 & Chernozems (ca,ha,lv,gc) & 12,790 & 16 \\
\hline 6 & Phaeozems (ha,ca,lv,st) & 68,200 & 1.7 \\
\hline 7 & Rendzinic leptosols & 7,245 & 8.7 \\
\hline 8 & Eutric cambisols (eu,mo,ca,st) & 37,077 & 6 \\
\hline 9 & Distric cambisols (ha,st,gz) & 25,575 & 23 \\
\hline 10 & Luvisols (ha,st,ab,mo,vr) & 98,020 & 0.03 \\
\hline 11 & Planosols (ha,ab) & 127 & 0.1 \\
\hline 12 & Entic podzols & 426 & 0.4 \\
\hline 13 & Podzols ( & 1,704 & 1.1 \\
\hline 14 & Stagnosols (ha,lv,ab,vr) & 4,687 & 2.5 \\
\hline 15 & Gleysols (ha,ca,mo) & 10,654 & 0.1 \\
\hline 16 & Solonchaks & 426 & 0.01 \\
\hline 17 & Solonetz & 42 & 6.17 \\
\hline 18 & Anthrosols (ho,er,dc) & 30,528 & 100 \\
\hline & TOTAL & 426,177 \\
\hline
\end{tabular}

in the mountains, 130 days in the hillside and 120 days in the rest of the county.

In these pedologyc-climatic conditions, the pedologyc blanket is highly variable, its formation is closely related to the conditions of relief, climate, parental rock, groundwater influence of periodic overflows of water and not least the anthropogenic influence (Table 2).

The table above shows that the soils from luvisols class are dominant, followed by protisols class and by the chernozems class. The other classes of soils are spread unevenly, with a lower weight and significance in agricultural production.

According to the classification system (SRTS2012, WRB-SR-1998), the main classes of soil show specific agrochemical features: the ones from luvisols class are characterized by low to moderately acidic $\mathrm{pH}$ having a medium to low content in humus, cernisoils being characterized by rich humus content and a $\mathrm{pH}$ neutral to the slightly alkaline. Regosols located on sunny slopes and formed on limestone and calcareous marls have a pH from low to moderately alkaline and a low content in humus and organic matter. Aluvosols have an extremely varied $\mathrm{pH}$ depending on the nature of fluvial deposits from which they evolved.

There are also soils that present extreme variations of $\mathrm{pH}$ : soils belonging to classes umbrisols and cambisols, podzols are characterized by moderate to strong acidic $\mathrm{pH}$, while at the other extreme are located soils belonging to the class salsodisoils (solonchaks, solonetz) with strong and very strong alkaline $\mathrm{pH}$.

Among the many agrochemical properties that characterize the soils are considered important in practical business presented for agricultural practice: soil reaction, humus content, total nitrogen, mobile phosphorus and mobile potassium.

After centralizing the data from the archive of OSPA Cluj, the situation is presented in table 3-7.

From the synthetic situation presented above results that primarily in Cluj County dominate moderately acidic and acid soils on over $50 \%$ of the area mapped. This situation is due in part to natural conditions in which these soils were formed, but a good portion were acidified in a relatively short time due to anthropogenic influences and here we refer primarily to the application of fertilizers 
Tab. 3. Structure of agricultural areas considering soil's reaction (ha)

\begin{tabular}{ccccccc}
\hline $\begin{array}{c}\text { Strongly } \\
\text { acidic }\end{array}$ & $\begin{array}{c}\text { Moderate } \\
\text { acidic }\end{array}$ & Low acidic & Neutral & Low alkaline & $\begin{array}{c}\text { Moderate } \\
\text { alkaline }\end{array}$ & $\begin{array}{c}\text { Strongly } \\
\text { alkaline }\end{array}$ \\
\hline $\mathrm{pH}=3.6-5.0$ & $\mathrm{pH}=5.1-5.8$ & $\mathrm{pH}=5.9-6.8$ & $\mathrm{pH}=6.9-7.2$ & $\mathrm{pH}=7.3-8.4$ & $\mathrm{pH}=8.4-9.0$ & $\mathrm{pH}=9.1-10$ \\
\hline 32,168 & 51,999 & 183,981 & 85,368 & 52,091 & 20,000 & 570 \\
\hline $7.54 \%$ & $12.20 \%$ & $43.17 \%$ & $20.03 \%$ & $12.22 \%$ & $4.69 \%$ & $0.14 \%$ \\
\hline
\end{tabular}

Tab. 4. Structure of agricultural areas considering the nitrogen content (ha)

\begin{tabular}{cccccc}
\hline Very small & Small & Medium & Big & Very big & Total \\
\hline$<0.100 \%$ & $0.101-140 \%$ & $0.141-0.270 \%$ & $0.271-0.600 \%$ & $>0.601 \%$ & \\
\hline 33,201 & 286,324 & 54,231 & 39,614 & 12,807 & 426,177 \\
\hline $7.79 \%$ & $67.19 \%$ & $12.72 \%$ & $9.30 \%$ & $3.0 \%$ & $100 \%$ \\
\hline
\end{tabular}

Tab. 5. Structure of agricultural areas considering the phosphorus content (ha)

\begin{tabular}{cccccc}
\hline Very small & Small & Medium & Big & Very big & Total \\
\hline $1-8 \mathrm{ppm}$ & $9-18 \mathrm{ppm}$ & $19-36 \mathrm{ppm}$ & $37-72 \mathrm{ppm}$ & $>73 \mathrm{ppm}$ & \\
\hline 105,231 & 218,136 & 82,087 & 18,362 & 2,361 & 426,177 \\
\hline $24.69 \%$ & $51.19 \%$ & $19.26 \%$ & $4.30 \%$ & $0.55 \%$ & $100 \%$ \\
\hline
\end{tabular}

Tab. 6. Structure of agricultural areas considering the potassium content (ha)

\begin{tabular}{cccccc}
\hline Very small & Small & Medium & Big & Very big & Total \\
\hline $1-65 \mathrm{ppm}$ & $66-130 \mathrm{ppm}$ & $131-200 \mathrm{ppm}$ & $201-300 \mathrm{ppm}$ & $>301 \mathrm{ppm}$ & \\
\hline 11,086 & 7,682 & 134,512 & 231,061 & 41,836 & 426,177 \\
\hline $2.60 \%$ & $1.81 \%$ & $31.56 \%$ & $54.21 \%$ & $9.82 \%$ & $100 \%$ \\
\hline
\end{tabular}

Tab. 7. Structure of agricultural areas considering the humus reserve (ha)

\begin{tabular}{cccccc}
\hline Very small & Small & Medium & Big & Very big & Total \\
\hline $1-60 \mathrm{t} / \mathrm{ha}$ & $61-120 \mathrm{t} / \mathrm{ha}$ & $121-160 \mathrm{t} / \mathrm{ha}$ & $161-200 \mathrm{t} / \mathrm{ha}$ & $>201 \mathrm{t} / \mathrm{ha}$ & \\
\hline 69,718 & 78,136 & 118,936 & 131,026 & 28,361 & 426,177 \\
\hline $16.36 \%$ & $18.33 \%$ & $27.9 \%$ & $30.75 \%$ & $6.65 \%$ & $100 \%$ \\
\hline
\end{tabular}

with a physiological acid reaction, without being based on a mapping of Agrochemical researches, and ceasing subsidies for programs of amending acidic soils after 2007.

In the period 1992-2007 were included in the program for amending acidic soils more than 60,000 ha, intervening in the I and II emergencies of the calcium amendment. The amended areas fell below 1,000 ha/year thereafter. At this rate we consider that in the next 20 years the proportion of acid soils will increase by at least 5-6\%.
Nor in terms of content of main nutrients is a positive evolution. And here we refer primarily to the content of phosphorus. From Table 5 it appears a fairly large proportion of soils have a deficient in phosphorus (70\%), lower than the limit of 30 35 ppm P (AL), considered as the threshold for satisfying crops with phosphorus. This situation was reached primarily due to errors in practicing farming systems, simplification of crop rotation in short rotations (e.g. wheat-maize) and quitting 
the application of organic fertilizers and mineral phosphorus.

Thus the phenomenon of "induced deficiency" caused by climatic conditions (low temperatures, excess or lack of moisture), soil compaction, or induced natural acidity as well as excess application of ammonium nitrate and urea.

\section{CONCLUSION}

Various conditions of relief, parental rock and climate have generated an extremely varied pedologycal blanket, which together determine the environment in which the spontaneous and cultivated vegetation grow and develop. In the territory of the county of Cluj, dominant are luvisols, chernozems and cambisols, followed by undeveloped soils (regosols, fluvisols) dispersed throughout the county's area.

In the soil monitoring program were identified soils that offer low edaphic conditions in terms of agrochemical in respect of culture plants: soil highly acidic or highly alkaline (solonetz, soloncheaks), but their weight however reduced in the mapped area.

In terms of soils reaction dominates low and moderately acidic soils (50\%) because of the climatic conditions and the application of fertilizers without an agrochemical basis.

Regarding the content of the main nutrients is observed primarily a deficiency of phosphorus ( $70 \%$ of the mapped surface), a deficiency induced by inappropriate agrotechnical works and wrong application of chemical and organic fertilizers.

The situation is relatively better in terms of potassium content (medium and high content over $70 \%$ of the mapped area) and humus content, though from last year humus reserve decreases primarily due to soil erosion.

\section{REFERENCES}

1. Bakos St. (1994). Pedologycal lifts in the Transylvanian Plain. Journal of Soil Science. (4) 42-46.

2. Bakos St., Miclaus V. (2001). Contributions to the study of sunny slopes from the Transylvanian Plain. University of Agricultural Sciences and Veterinary Medicine, ClujNapoca, Reverential symposium, (2) 298-303.

3. Bakos St. (2001). Soils on the sunny slopes from the Transylvanian Plain, PhD Thesis, University of Agricultural Sciences and Veterinary Medicine, Cluj-Napoca.

4. Florea N., Balaceanu V., Rauta C., Canarache A. (1987). Methodology elaborating soil studies. Vol. I, II and III, Editor of Agricultural Propaganda, Bucharest.

5. Florea N., Munteanu I., (2012). Romanian system of soil classification, Sitech Publishing House, Craiova.

6. Marghitas M., Mihai M., Toader C., Moldovan L., Roman G. (2011). Handbook of agricultural plant fertilization technology. Academic Press Publishing House, ClujNapoca.

7. Rusu M., Marghitas M., Mihailescu T., Oroian I., Dumitras A. (2005). Treaty of agrochemical studies, Ceres Publishing House, Cluj-Napoca.

8. ***, OSPA Archives, Cluj-Napoca.

9. ***, (1997), Geography of Romania, Academic Publishing House, Bucharest. 